\title{
2. Escaping from Poverty: Household Income Dynamics in Indonesia, South Africa, Spain, and Venezuela
}

GARY S. FIELDS, PAUL L. CICHELLO, SAMUEL FREIJE, MARTA MENÉNDEZ, AND DAVID NEWHOUSE*

Opponents of free trade argue that in today's global economy, unfettered access to foreign capital, technology, and goods primarily benefits a well-connected and highly skilled elite, to the exclusion of the poor, voiceless majority. Are the rich getting richer at the expense of the poorer?

Are those who started out poor in fact getting poorer? And who gets ahead more: those who started out richer or those who started out poorer? These are some of the questions that this study addresses. It draws on data from four very different economies-Indonesia, South Africa, Spain, and Venezuela-and follows households over time during the period of intensifying globalization in the 1990s. The data reveal major patterns-some expected and some unexpected - that indicate that the intense economic activity of the 1990s did reach down to the poor in far-flung spots around the world. Poor households participated at least proportionately in the economic growth that has taken place.

This study presents the main results of a larger, more technical report (Fields and others 2001) and subsequent work (Fields and others 2002) that analyzes income mobility in Indonesia, South Africa, Spain, and Venezuela. These economies were selected on the basis of the availability of panel data with which to analyze household income dynamics in the 1990s. ${ }^{1}$ By following households over time, we are able to investigate how households that were poor initially fared economically, relative to their richer counterparts. We can learn more about how and why households exit-and enter-poverty.

To gauge income mobility, this study centers on the change in household per capita income over time, using two measures. Our first measure-a conventional one-gauges 
income changes in currency units. Our second measure, the change in log currency units, approximates the percentage changes in income. In this way, it arguably better reflects the reality of a poor household, in which a given change in income-whether an increase or a decrease-counts more than it does in a richer one.

To gauge a household's economic well-being in the base year, this study uses both reported income and predicted income (in currency units and in logs). The reason for using predicted income in addition to or in place of reported income is that household incomes are notoriously difficult to measure in survey data. In our particular context, any errors in the measure of income in the initial year will lead to overstatements in the income gains of the poor relative to the rich. We predicted income using time-invariant characteristics, base-year characteristics, assets, household expenditure per capita, and local average income. ${ }^{2}$

To get a first look at the movement of income over time, we divided households into five equal-size groups, or quintiles, for each country. The poorest are the first 20 percent of households (quintile 1). The next poorest 20 percent are in quintile 2 , and so on, up to the richest 20 percent in quintile 5. The movement from quintile to quintile is displayed in quintile transition matrices. Rows indicate the initial income quintile of the household, while columns indicate the final quintile of the household. Table 2-1 presents quintile transition matrices for Indonesia, South Africa, Spain, and Venezuela for different spans in the 1993-98 period.

Substantial short-term economic mobility took place in all four of these economies. Although there was movement in all four countries, Spain and Venezuela exhibited less quintile mobility than Indonesia and South Africa. This result can partly if not primarily be attributed to the shorter time interval between surveys in the first two countries (one year in each) than in the latter countries (four and four and one-half years, respectively). As has been found in other countries, those who started in the highest income quintile are more likely to remain there than any other pairing between base and final quintile. That is, the highest values appear in the 5,5 cells. The richest stay rich.

Why exactly do different types of households experience gains or losses in their per capita income (PCI)? Our study investigated five questions. First, did the rich, in fact, benefit more than the poor? That is, did households that were initially advantaged gain

Table 2-1 Quintile Transition Matrices

\begin{tabular}{l}
$\begin{array}{l}\text { Indonesia: Per Capita Income Transition Matrix } \\
\text { (percent of sample in } \\
1997\end{array}$ log PCI quintile, conditional on $1993 \log \mathrm{PCI}$ quintile) \\
\hline Years/initial quintile
\end{tabular}


Table 2-1 (continued)

\begin{tabular}{|c|c|c|c|c|c|}
\hline \multirow{2}{*}{$\begin{array}{l}\text { Years/initial quintile } \\
1993 / 1998\end{array}$} & \multicolumn{5}{|c|}{ Final quintile } \\
\hline & 1 & 2 & 3 & 4 & 5 \\
\hline 1 & 38.2 & 20.6 & 17.6 & 13.4 & 10.3 \\
\hline 2 & 26.9 & 29.3 & 24.3 & 12.3 & 7.3 \\
\hline 3 & 18.4 & 22.6 & 22.5 & 22.6 & 14.0 \\
\hline 4 & 12.8 & 18.4 & 24.3 & 25.7 & 18.9 \\
\hline 5 & 3.7 & 9.2 & 11.7 & 25.8 & 49.6 \\
\hline
\end{tabular}

Spain: Per Capita Income Transition Matrix (percent of sample in $1996 \log$ PCI quintile, conditional on $1995 \log$ PCI quintile)

\begin{tabular}{lrrrrr}
\hline \multirow{2}{*}{ Years/initial quintile } & \multicolumn{5}{c}{ Final quintile } \\
\cline { 2 - 6 } $1995 / 1996$ & \multicolumn{1}{c}{1} & \multicolumn{1}{c}{2} & \multicolumn{1}{c}{3} & \multicolumn{1}{c}{} \\
\hline 1 & $\mathbf{6 5 . 4}$ & 22.2 & 6.0 & 5.4 & 5 \\
2 & 19.7 & $\mathbf{5 6 . 3}$ & 17.0 & 5.7 & 1.1 \\
3 & 3.4 & 23.4 & $\mathbf{5 3 . 1}$ & 17.2 & 2.9 \\
4 & 2.1 & 3.9 & 20.3 & $\mathbf{5 8 . 0}$ & 15.7 \\
5 & 0.0 & 0.7 & 2.4 & 18.9 & $\mathbf{7 8 . 1}$ \\
\hline
\end{tabular}

Venezuela: Per Capita Income Transition Matrix

(percent of sample in $1998 \log$ PCI quintile, conditional on $1997 \log$ PCI quintile)

\begin{tabular}{lrrrrr}
\hline \multirow{2}{*}{ Year/initial quintile } & \multicolumn{5}{c}{ Final quintile } \\
\cline { 2 - 6 } $1997 / 1998$ & \multicolumn{1}{c}{1} & 2 & 3 & 4 & 5 \\
\hline 1 & $\mathbf{4 9 . 5}$ & 23.0 & 14.6 & 9.6 & 3.3 \\
2 & 25.2 & 29.8 & 23.6 & 14.7 & 6.7 \\
3 & 17.6 & 21.8 & $\mathbf{2 7 . 4}$ & 21.8 & 11.4 \\
4 & 10.3 & 11.7 & 22.4 & $\mathbf{3 4 . 7}$ & 20.8 \\
5 & 3.8 & 5.1 & 11.0 & 21.0 & $\mathbf{5 9 . 2}$ \\
\hline
\end{tabular}

Note: Numbers in bold reflect no movement from initial quintile to final quintile.

Source: Authors calculations, based on the following household surveys: (Indonesia) the Indonesian Family Life Survey for 1993 and 1997; (South Africa) KwaZulu-Natal Income Dynamics Study for 1993 and 1998; (Spain) the Spanish Household Panel Survey (Encuesta Contínua de Presupuestos Familiares) from 1995 and 1996; and (Venezuela) the Venezuelan Sample Household Survey (Encuesta de Hogares por Muestreo) from 1997 and 1998.

more or less, on average, than households that were initially poor? Second, did households with higher incomes than would have been predicted, given their observed characteristics, build upon their advantage or fall back to their expected income? For two initially similar households, did the one that started in a better position, thanks to good luck or unobserved skills, extend its advantage? Third, which household characteristics are most important in accounting for the different changes in households' per capita income? The study examined a variety of household characteristics, including initial income, job changes, demographic composition of the household, and 
education levels of the head. Fourth, in explaining change in per capita income, what is the relative importance of changes in income as compared to changes in household size, and how important are changes in each source of income? Finally, which household characteristics are associated with the ability of initially poor households to escape from destitution?

\section{HOUSEHOLD INCOME DYNAMICS AND BASE-YEAR INCOME: INITIAL RESULTS}

Who gets ahead more: those who started out richer or those who started out poorer? Does poverty persist? Do households escaping poverty offset those falling into it over time? Do household per capita incomes converge toward the country's average income or diverge away from it?

Our first test uses linear regression. Let $\mathrm{Y}_{1}$ denote a measure of a household's base-year economic position (such as per capita income or consumption). Similarly, $Y_{2}$ represents final-year economic position. Let $\Delta Y$ denote the difference between reported $Y_{2}$ and reported $Y_{1} . A$ number of previous studies have regressed $\Delta Y$ on $Y_{1}$ (or $Y_{2}$ on $Y_{1}$ ) with no other variables present. If $\Delta Y$ is found to rise as $Y_{1}$ rises, the base-year rich are getting ahead by more. This is called "unconditional divergence." Households are moving further apart relative to where they started. On the other hand, if it is the base-year poor who are getting ahead by more, $\Delta \mathrm{Y}$ will fall as $\mathrm{Y}_{1}$ rises. This is called "unconditional convergence." In this case, the gap between high income and low income households is narrowing. A third possibility is "independence": that is, the base-year poor and base-year rich experience the same changes in income. The gap remains, but rich and poor alike are better off-or worse off-by about the same amount.

The coefficients for regressions of this type for our four countries are presented in Table 2-2. Four measures of economic position and its change are used: reported log income per capita, predicted log income per capita, reported income per capita, and predicted income per capita.

By two measures, the research indicates that it is the poor who are getting ahead by more than the rich. The first row of Table 2-2 demonstrates unconditional convergence of reported per capita income, measured in log terms, in all four countries. The second row demonstrates that reported incomes, measured in monetary terms, also converge toward the country's mean per capita income. That is, when looking at reported incomes, those with initially low incomes gain more rupiah, rand, pesetas, or bolivares than do higher-income households.

The results of the regression relating change in income to predicted base-year income are reported in the bottom two rows of Table 2-2. The changes in estimated $\log$ PCI are significantly negatively related to base $\log$ PCI: that is, in all four countries, the higher is a household's estimated base-year log PCI, the lower is its estimated change in $\log$ PCI. However, no such uniformity is found for changes in currency units. Although the same convergent pattern is found for South Africa and Venezuela, no significant relationship is found for Spain, and a significant positive (that is, divergent) effect is found for Indonesia. 
Table 2-2 Coefficients from a Regression of Income Change on Base-year Income

\begin{tabular}{|c|c|c|c|c|c|}
\hline \multirow{2}{*}{$\begin{array}{l}\begin{array}{l}\text { Dependent } \\
\text { variable }\end{array} \\
\begin{array}{r}\text { Change in } \\
\text { log PCI }\end{array}\end{array}$} & \multirow{2}{*}{$\begin{array}{l}\text { Base-year } \\
\text { income }\end{array}$} & \multicolumn{2}{|c|}{ Indonesia } & \multicolumn{2}{|c|}{ South Africa } \\
\hline & & $-0.50^{\star}$ & $\begin{array}{l}\text { Unconditional } \\
\text { convergence }\end{array}$ & $-0.56^{\star}$ & $\begin{array}{r}\text { Unconditional } \\
\text { convergence }\end{array}$ \\
\hline Change in $\mathrm{PCI}$ & $\begin{array}{l}\text { Reported } \\
\text { income }\end{array}$ & $-0.23^{\star}$ & $\begin{array}{r}\text { Unconditional } \\
\text { convergence }\end{array}$ & $-0.36^{\star}$ & $\begin{array}{r}\text { Unconditional } \\
\text { convergence }\end{array}$ \\
\hline $\begin{array}{r}\text { Change in } \\
\log \mathrm{PCI}\end{array}$ & $\begin{array}{l}\text { Predicted } \\
\text { log income }\end{array}$ & $-0.23^{\star}$ & $\begin{array}{l}\text { Unconditional } \\
\text { convergence }\end{array}$ & $-0.36^{\star}$ & $\begin{array}{r}\text { Unconditional } \\
\text { convergence }\end{array}$ \\
\hline Change in $\mathrm{PCl}$ & $\begin{array}{l}\text { Predicted } \\
\text { income }\end{array}$ & $0.13^{\star}$ & $\begin{array}{l}\text { Unconditional } \\
\text { divergence }\end{array}$ & $-0.21^{\star}$ & $\begin{array}{r}\text { Unconditional } \\
\text { convergence }\end{array}$ \\
\hline $\begin{array}{l}\text { Dependent } \\
\text { variable }\end{array}$ & $\begin{array}{l}\text { Base-year } \\
\text { income }\end{array}$ & & Spain & \multicolumn{2}{|c|}{ Venezuela } \\
\hline $\begin{array}{r}\text { Change in } \\
\log \mathrm{PCI}\end{array}$ & $\begin{array}{l}\text { Reported } \\
\text { log income }\end{array}$ & $-0.52^{\star}$ & $\begin{array}{l}\text { Unconditional } \\
\text { convergence }\end{array}$ & $-0.64 \star$ & $\begin{array}{r}\text { Unconditional } \\
\text { convergence }\end{array}$ \\
\hline Change in PCI & $\begin{array}{l}\text { Reported } \\
\text { income }\end{array}$ & $-0.07 \star$ & $\begin{array}{l}\text { Unconditional } \\
\text { convergence }\end{array}$ & $-0.35^{\star}$ & $\begin{array}{l}\text { Unconditional } \\
\text { convergence }\end{array}$ \\
\hline $\begin{array}{r}\text { Change in } \\
\log \text { PCI }\end{array}$ & $\begin{array}{l}\text { Predicted } \\
\qquad \log \text { income }\end{array}$ & $-0.13 \star$ & $\begin{array}{r}\text { Unconditional } \\
\text { convergence }\end{array}$ & $-0.21^{\star}$ & $\begin{array}{r}\text { Unconditional } \\
\text { convergence }\end{array}$ \\
\hline Change in PCI & $\begin{array}{l}\text { Predicted } \\
\text { income }\end{array}$ & 0.01 & None & $-0.37^{\star}$ & $\begin{array}{r}\text { Unconditional } \\
\text { convergence }\end{array}$ \\
\hline
\end{tabular}

*Denotes statistical significance at the $5 \%$ level.

Source: Authors' calculations.

To test the robustness of the preceding conclusions, we performed two other kinds of tests. One is to use other measures of base-year economic position (Tables 2-3a and $2-3 b)$. Non-parametric regressions were also performed to shed light on the earlier results based on linear regressions. The Indonesia results are displayed in Figures 2-1a2-1d. These alternative measures of base-year economic position (fitted initial income quintile, initial consumption quintile, initial asset quintile, and initial housing rent) can be thought of as alternative indicators of longer-term economic well-being. Using these indicators, the analysis reinforced all the previous results. With one exception, a pronounced negative or an independent relationship appeared between base-year economic position, on the one hand, and subsequent income change, on the other. The one exception is that longer-term well-being is associated with a higher change in monetary terms in Indonesia. The second test involves simulating the effect of possible measurement error in income on our results. This analysis found that the unconditional convergence results appear to be robust in South Africa and Venezuela, but that unconditional divergence may well have taken place in Spain (Fields and others 2002).

In sum, initially poor households appeared to do better than initially rich households in terms of percentage gains. In currency terms, changes appear mixed across countries, with strong evidence of larger income gains for lower-income households in South Africa and Venezuela and some evidence of larger gains for higher income households in Indonesia and Spain. 
Table 2-3a Mobility Profiles by Initial Position: Mean Changes in Log PCI

\begin{tabular}{|c|c|c|c|c|c|c|c|c|}
\hline & \multicolumn{2}{|c|}{ Indonesia } & \multicolumn{2}{|c|}{ South Africa } & \multicolumn{2}{|c|}{ Spain } & \multicolumn{2}{|c|}{ Venezuela } \\
\hline & Mean & $\begin{array}{l}\text { Std. } \\
\text { dev. }\end{array}$ & Mean & $\begin{array}{l}\text { Std. } \\
\text { dev. }\end{array}$ & Mean & $\begin{array}{l}\text { Std. } \\
\text { dev. }\end{array}$ & Mean & $\begin{array}{l}\text { Std. } \\
\text { dev. }\end{array}$ \\
\hline Total population & 0.37 & 0.02 & 0.15 & 0.05 & 0.076 & 1.05 & -0.043 & 0.036 \\
\hline \multicolumn{9}{|l|}{ BY INITLAL INCOME } \\
\hline QUINTILE & $\star$ & & $\star$ & & $\star$ & & $\star$ & \\
\hline Poorest quintile & 1.47 & 0.07 & 1.10 & 0.14 & 0.27 & 0.17 & 1.150 & 0.118 \\
\hline 2nd quintile & 0.42 & 0.05 & 0.23 & 0.08 & 0.06 & 0.02 & -0.150 & 0.060 \\
\hline 3rd quintile & 0.16 & 0.04 & 0.08 & 0.09 & -0.01 & 0.05 & -0.461 & 0.075 \\
\hline 4 th quintile & -0.00 & 0.03 & -0.19 & 0.10 & 0.00 & 0.02 & -0.335 & 0.049 \\
\hline Richest quintile & -0.20 & 0.03 & -0.46 & 0.07 & -0.02 & 0.01 & -0.408 & 0.027 \\
\hline \multicolumn{9}{|l|}{ BY FITIED INITIAL } \\
\hline INCOME QUINTILE & $\star$ & & $\star$ & & & & & \\
\hline Poorest quintile & 0.67 & 0.06 & 0.62 & 0.14 & 0.04 & 0.08 & 0.065 & 0.075 \\
\hline 2nd quintile & 0.38 & 0.04 & 0.18 & 0.08 & 0.05 & 0.07 & -0.188 & 0.090 \\
\hline 3rd quintile & 0.32 & 0.04 & 0.22 & 0.12 & 0.01 & 0.08 & -0.021 & 0.078 \\
\hline 4th quintile & 0.23 & 0.04 & -0.01 & 0.09 & 0.06 & 0.03 & -0.030 & 0.059 \\
\hline Richest quintile & 0.12 & 0.04 & -0.23 & 0.07 & 0.14 & 0.09 & -0.041 & 0.065 \\
\hline \multicolumn{9}{|c|}{ BY INITIAL CONSUMPTION } \\
\hline QUINTILE & $\star$ & & $\star$ & & & & & \\
\hline Poorest quintile & 0.54 & 0.05 & 0.47 & 0.11 & 0.06 & 0.16 & & \\
\hline 2nd quintile & 0.36 & 0.05 & 0.20 & 0.10 & 0.02 & 0.04 & & \\
\hline 3 rd quintile & 0.32 & 0.04 & 0.20 & 0.10 & 0.06 & 0.02 & & \\
\hline 4th quintile & 0.37 & 0.04 & 0.14 & 0.10 & 0.04 & 0.04 & & \\
\hline Richest quintile & 0.25 & 0.04 & -0.23 & 0.07 & 0.14 & 0.06 & & \\
\hline \multicolumn{9}{|l|}{ BY INITIAL } \\
\hline ASSET QUINTILE & $\star$ & & & & & & & \\
\hline Poorest quintile & 0.54 & 0.05 & & & & & & \\
\hline 2nd quintile & 0.36 & 0.05 & & & & & & \\
\hline 3rd quintile & 0.32 & 0.04 & & & & & & \\
\hline 4th quintile & 0.37 & 0.04 & & & & & & \\
\hline Richest quintile & 0.25 & 0.04 & & & & & & \\
\hline \multicolumn{9}{|l|}{ BY INITIAL HOUSING } \\
\hline \multicolumn{9}{|l|}{ RENT QUINTILE } \\
\hline Poorest quintile & & & & & 0.06 & 0.09 & & \\
\hline 2nd quintile & & & & & 0.07 & 0.02 & & \\
\hline 3rd quintile & & & & & -0.01 & 0.07 & & \\
\hline 4th quintile & & & & & 0.05 & 0.03 & & \\
\hline Richest quintile & & & & & 0.14 & 0.10 & & \\
\hline
\end{tabular}

$\star$ Denotes statistical significance at the $5 \%$ level using an F-test on category variables.

Source: Authors' calculations.

\section{HOUSEHOLD INCOME DYNAMICS AND BASE-YEAR INCOME: MULTIVARIATE ANALYSIS}

The research reported in the previous section supports the finding that households tended to move closer to their country's overall mean income in South Africa and Venezuela. That finding leads to another question: do households that start ahead of households with similar observable characteristics move further ahead or do they tend to fall toward the level of their peers? If the first pattern is found, the results would 
Table 2-3b Mobility Profiles by Initial Position: Mean Changes in Per Capita Income

\begin{tabular}{|c|c|c|c|c|c|c|c|c|}
\hline & \multicolumn{2}{|c|}{ Indonesia } & \multicolumn{2}{|c|}{ South Africa } & \multicolumn{2}{|c|}{ Spain } & \multicolumn{2}{|c|}{ Venezuela } \\
\hline & Mean & $\begin{array}{l}\text { Std. } \\
\text { dev. }\end{array}$ & Mean & $\begin{array}{l}\text { Std. } \\
\text { dev. }\end{array}$ & Mean & $\begin{array}{l}\text { Std. } \\
\text { dev. }\end{array}$ & Mean & $\begin{array}{l}\text { Std. } \\
\text { dev. }\end{array}$ \\
\hline Total population & 17.8 & 1.3 & 46.5 & 13.7 & 9.24 & 48.41 & 2.19 & 0.86 \\
\hline \multicolumn{9}{|l|}{ BY INITIAL INCOME } \\
\hline QUINTILE & $\star$ & & $\star$ & & $\star$ & & $\star$ & \\
\hline Poorest quintile & 26.7 & 1.7 & 140.88 & 23.00 & 20.99 & 2.36 & 20.66 & 1.17 \\
\hline 2nd quintile & 22.6 & 1.8 & 73.57 & 15.75 & 11.45 & 2.43 & 13.44 & 1.04 \\
\hline 3rd quintile & 21.9 & 1.8 & 85.26 & 21.26 & 9.88 & 2.83 & 8.20 & 1.32 \\
\hline 4th quintile & 18.1 & 2.2 & 33.81 & 26.29 & 7.12 & 3.51 & -0.53 & 1.49 \\
\hline Richest quintile & -0.2 & 4.0 & -101.73 & 37.95 & -2.60 & 4.13 & -31.83 & 2.94 \\
\hline \multicolumn{9}{|l|}{ BY FITTED INITIAL } \\
\hline INCOME QUINTILE & * & & $\star$ & & & & & \\
\hline Poorest quintile & 13.8 & 1.1 & 69.74 & 14.86 & 6.01 & 2.50 & 4.46 & 0.96 \\
\hline 2nd quintile & 15.3 & 1.6 & 50.2 & $\cdot 15.82$ & 9.14 & 2.27 & 4.03 & 1.11 \\
\hline 3rd quintile & 14.4 & 2.0 & 104.28 & 26.56 & 11.78 & 3.10 & 3.05 & 1.27 \\
\hline 4th quintile & 23.0 & 2.4 & 35.01 & 24.59 & 9.19 & 3.20 & 0.05 & 1.73 \\
\hline Richest quintile & 26.0 & 4.4 & -21.74 & 30.93 & 11.07 & 3.64 & 0.15 & 2.75 \\
\hline \multicolumn{9}{|c|}{ BY INITIAL CONSUMPTION } \\
\hline QUINTILE & $\star$ & & $\star$ & & & & & \\
\hline Poorest quintile & 10.4 & 1.2 & 66.68 & 15.26 & 9.21 & 2.71 & & \\
\hline 2nd quintile & 16.9 & 1.7 & 40.65 & 15.24 & 2.27 & 2.38 & & \\
\hline 3rd quintile & 16.6 & 1.8 & 74.01 & 21.32 & 10.23 & 3.05 & & \\
\hline 4th quintile & 21.3 & 2.2 & 90.92 & 28.33 & 12.15 & 3.81 & & \\
\hline Richest quintile & 26.2 & 4.2 & -34.11 & 30.51 & 13.53 & 4.20 & & \\
\hline BY INITIAL & & & & i & & & & \\
\hline ASSET QUINTILE & $\star$ & & & & & & & \\
\hline Poorest quintile & 18.4 & 1.8 & & & & & & \\
\hline 2nd quintile & 12.8 & 1.7 & & & & & & \\
\hline 3rd quintile & 12.0 & 1.9 & & & & & & \\
\hline 4th quintile & 19.3 & 2.4 & & & & & & \\
\hline Richest quintile & 27.9 & 3.3 & & & & & & \\
\hline \multicolumn{9}{|c|}{ BY INITLAL HOUSING } \\
\hline \multicolumn{9}{|c|}{ RENT QUINTILE } \\
\hline Poorest quintile & & & & & 7.35 & 2.64 & & \\
\hline 2nd quintile & & & & & 8.79 & 2.58 & & \\
\hline 3rd quintile & & & & & 8.96 & 2.73 & & \\
\hline 4th quintile & & & & & 6.40 & 3.43 & & \\
\hline Richest quintile & & & & & 15.48 & 4.00 & & \\
\hline
\end{tabular}

$\star$ Denotes statistical significance at the $5 \%$ level using an F-test on category variables.

Source: Authors' calculations.

be evidence in favor of the classic cumulative advantage hypothesis of Merton (1968): that those who start ahead get further ahead. In the second case, though, the evidence would support one form of the classic permanent income hypothesis of Friedman and Kuznets (1945): that households have permanent incomes from which they are shocked and to which they return.

The study used multiple regression analysis to carry out conditioning: that is, to determine the income that would be expected from the household's characteristics. 


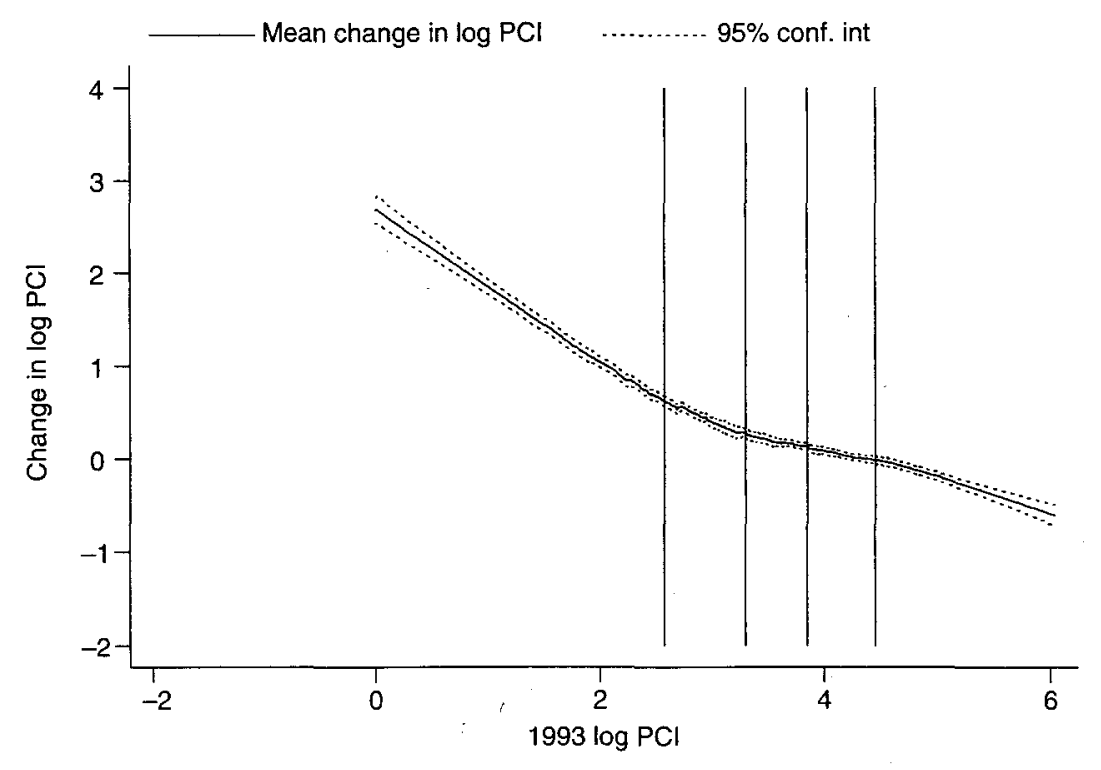

Figure 2-1a. Non-parametric Regression for Change in Log PCI on Initial Log PCI, Indonesia, $1993-98$. Note: Extreme outlier data not shown.

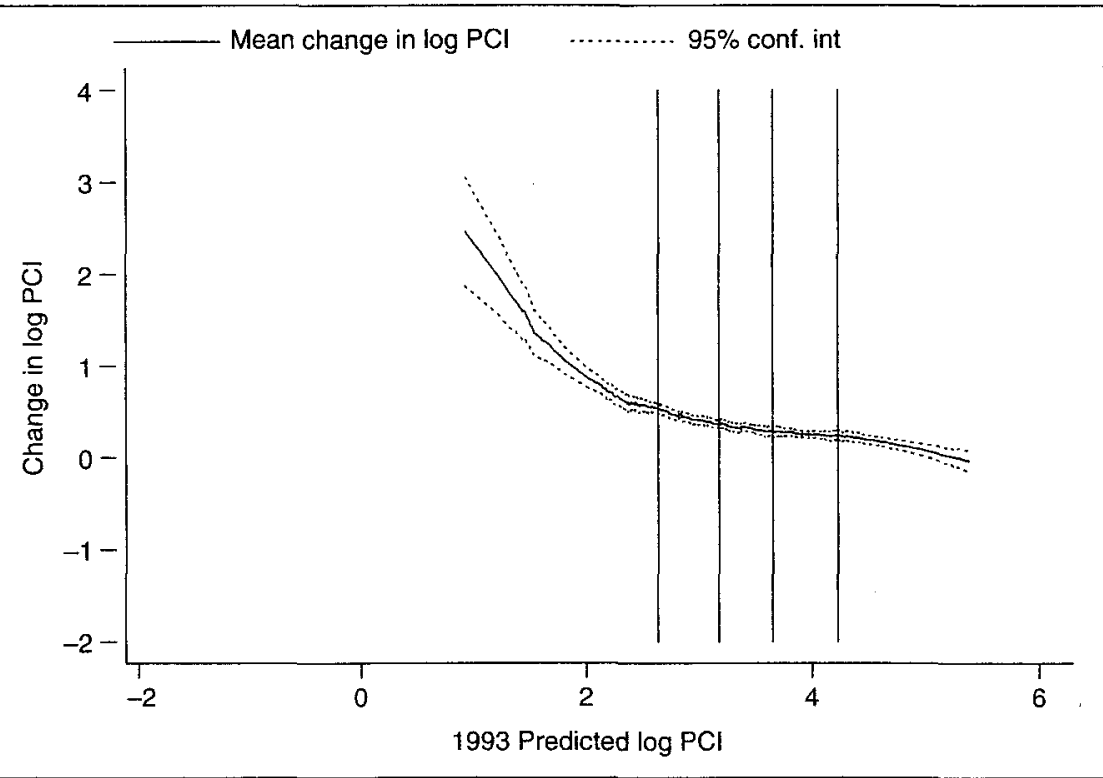

Figure 2-1b. Non-paramétric Regression for Change in Log PCI on Prédicted Log PCI, Indonesia, 1993-98.

Note: Extreme outlier data not shown. 


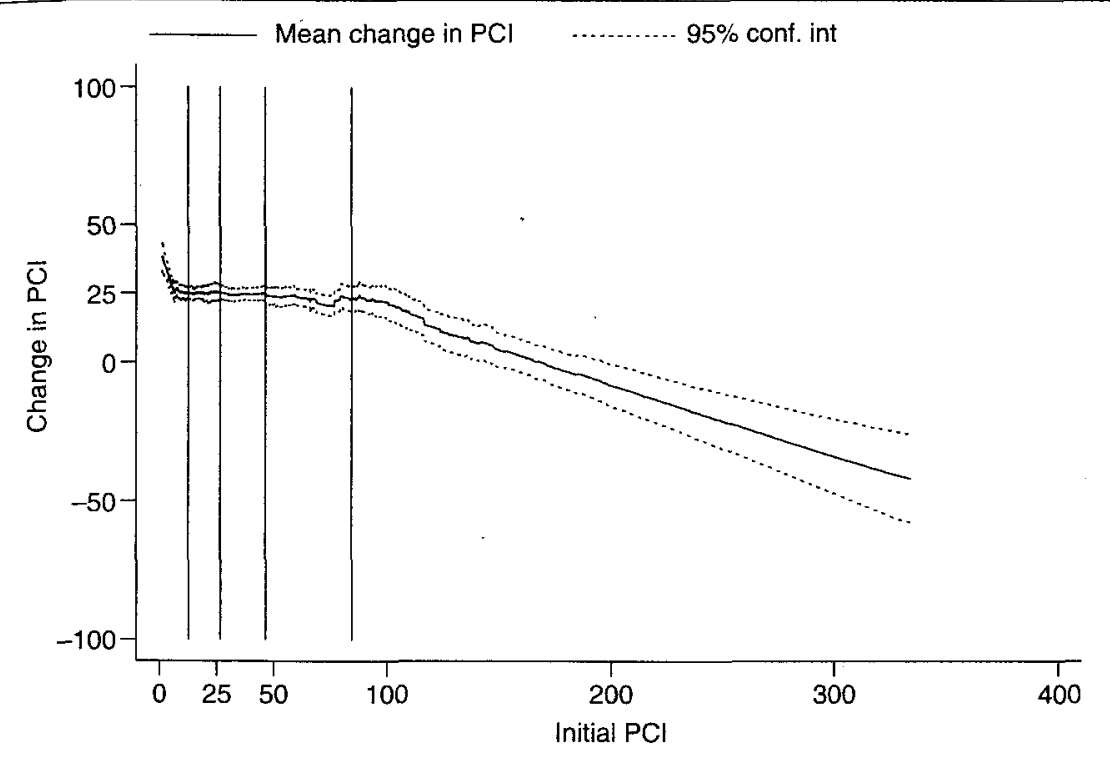

Figure 2-1c. Non-parametric Regression for Change in $\mathrm{PCl}$ on Initial PCI, Indonesia, 1993-98. Note: Extreme outlier data not shown.

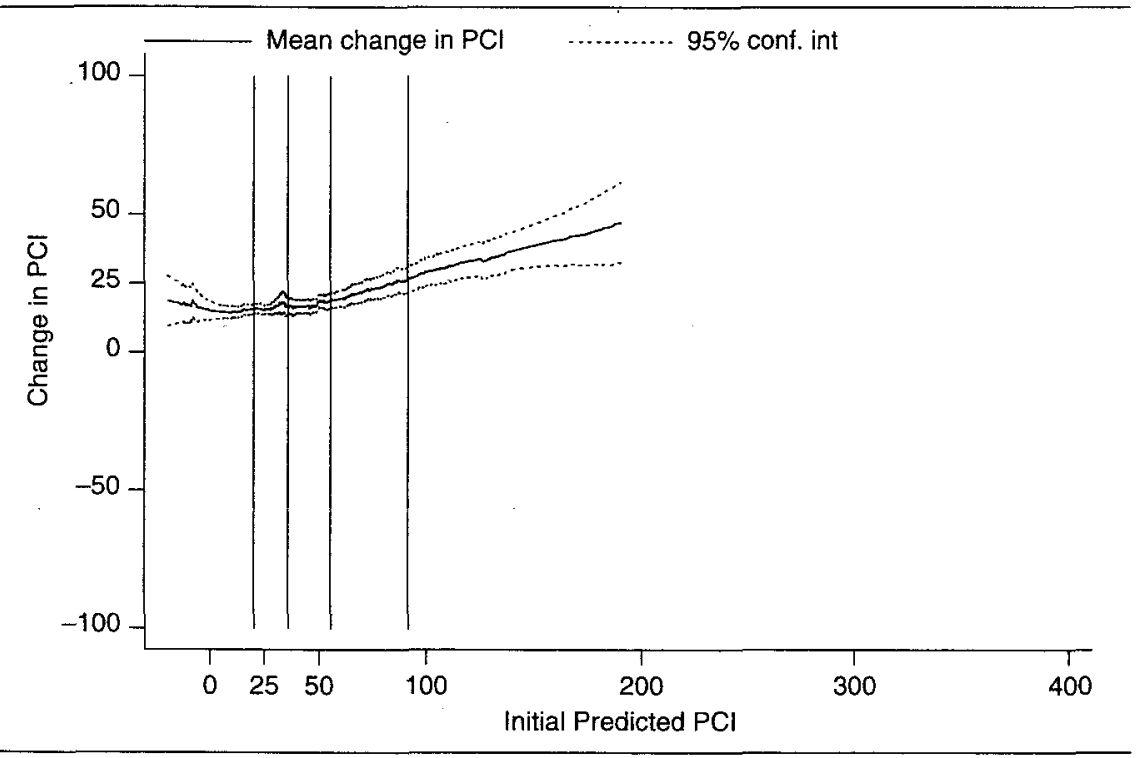

Figure 2-1d. Non-parametric Regression for Change in PCI on Initial Predicted PCI, Indonesia, 1993-98.

Note: Extreme outlier data not shown. 
The dependent variables in the regressions are changes in PCI, whether measured in $\log$ units or in currency units. Explanatory variables include time-invariant characteristics, time-varying characteristics in the base year and in the subsequent year, and base-year income. We ran Ordinary Least Squares regressions using both base-year reported income and, to correct for measurement error in the income variables, base-year predicted income.

The coefficients on base-year income in these regressions may be interpreted as follows. Suppose that the economy is growing, so that the families with a given set of characteristics are achieving income gains over time. How do the changes in income of those households that start with incomes greater than expected, given their characteristics, compare with those that start below? Four possibilities may be distinguished, as shown in Figure 2-2:

- Full conditional convergence: On average, households that started above their expected income and households that started below their expected income converge to the same final-year income.

- Partial conditional convergence: On average, households that started above their expected income fall closer to it and those that started below their expected income rise closer to it.

- Independence: On average, households that started above their expected income and those that started below get ahead at the same rate.

- Conditional divergence: On average, households that started above their expected income get even further ahead, while those that started below their expected income get ahead less rapidly or even fall behind.

The tests of these four hypotheses are gauged by the coefficients on the base-year income variable in the income change regressions described above:

- Full conditional convergence: coefficient $=-1$.

- Partial conditional convergence: coefficient is between -1 and 0 .

- Independence (as defined in the previous paragraph): coefficient $=0$.

- Conditional divergence: coefficient $>0$.

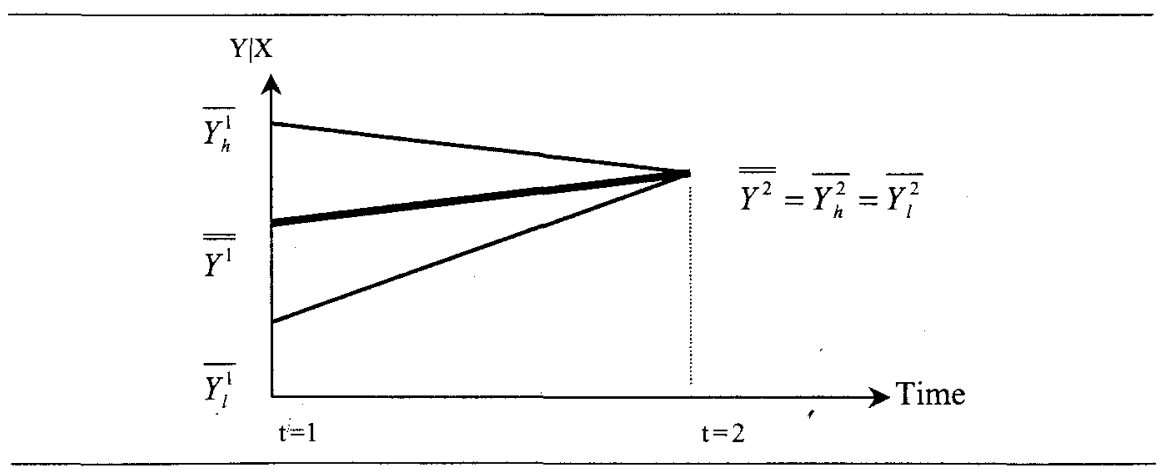

Figure 2-2a. Full Conditional Convergence. 


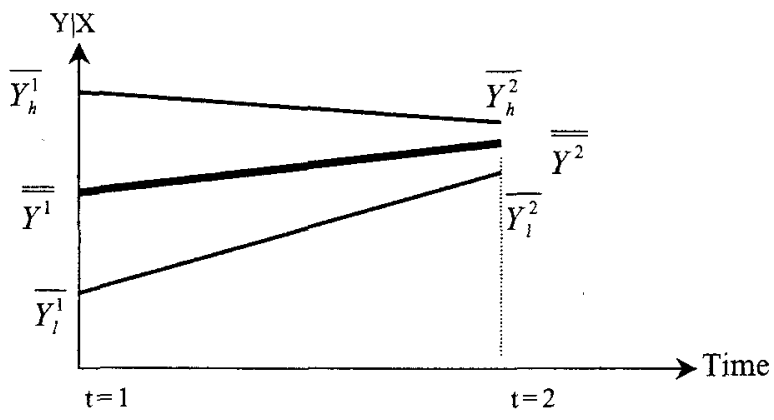

Figure 2-2b. Partial Conditional Convergence.

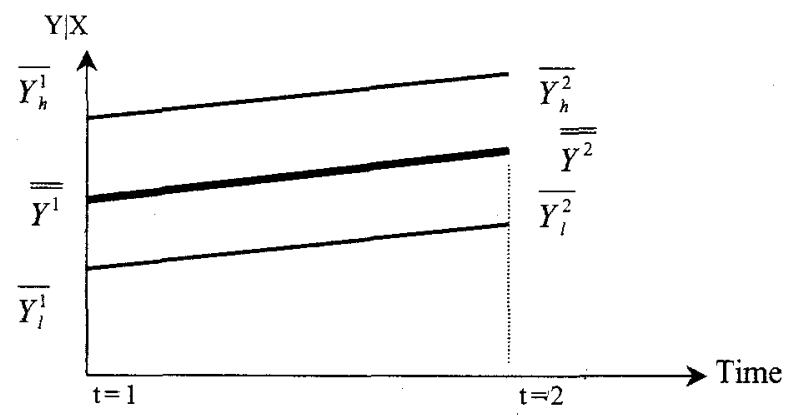

Figure 2-2c. Independence.

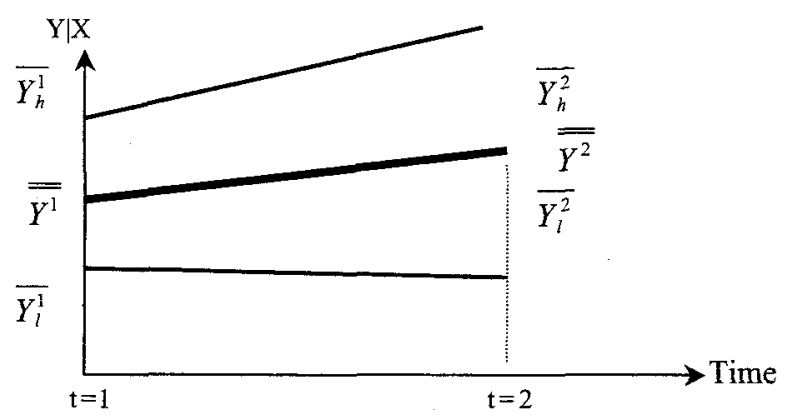

Figure 2-2d. Conditional Divergence.

The regression coefficients obtained empirically are summarized in Table $2-4$. When reported income is used, partial conditional convergence appears in all four countries, both for change in $\log \mathrm{PCI}$ and for change in PCI. On the other hand, when initial income is predicted, partial conditional convergence is found in South Africa, but 
Table 2-4 Regression of Income Change on Base-year Income, Controlling for Household Characteristics

\begin{tabular}{|c|c|c|c|c|c|}
\hline \multirow{2}{*}{$\begin{array}{l}\begin{array}{l}\text { Dependent } \\
\text { variable }\end{array} \\
\begin{array}{c}\text { Change in } \\
\text { log PCI }\end{array}\end{array}$} & \multirow{2}{*}{$\begin{array}{l}\begin{array}{l}\text { Base-year } \\
\text { income }\end{array} \\
\begin{array}{c}\text { Reported } \\
\text { log income }\end{array}\end{array}$} & \multicolumn{2}{|c|}{ Indonesia } & \multicolumn{2}{|c|}{ South Africa } \\
\hline & & $-0.66^{\star}$ & $\begin{array}{l}\text { Conditional } \\
\text { convergence }\end{array}$ & $-0.80^{\star}$ & $\begin{array}{l}\text { Conditional } \\
\text { convergence }\end{array}$ \\
\hline Change in $\mathrm{PCI}$ & $\begin{array}{r}\text { Reported } \\
\text { income }\end{array}$ & $-0.42^{\star}$ & $\begin{array}{l}\text { Conditional } \\
\text { convergence }\end{array}$ & $-0.54^{\star}$ & $\begin{array}{l}\text { Conditional } \\
\text { convergence }\end{array}$ \\
\hline $\begin{array}{r}\text { Change in } \\
\text { log PCI }\end{array}$ & $\begin{array}{l}\text { Predicted } \\
\text { log income }\end{array}$ & $-0.37^{\star}$ & $\begin{array}{l}\text { Conditional } \\
\text { convergence }\end{array}$ & $-0.58^{\star}$ & $\begin{array}{l}\text { Conditional } \\
\text { convergence }\end{array}$ \\
\hline Change in PCI & $\begin{array}{l}\text { Predicted } \\
\text { income }\end{array}$ & -0.08 & None & $-0.37^{\star}$ & $\begin{array}{l}\text { Conditional } \\
\text { convergence }\end{array}$ \\
\hline $\begin{array}{l}\text { Dependent } \\
\text { variable }\end{array}$ & $\begin{array}{l}\text { Base-year } \\
\text { income }\end{array}$ & & Spain & \multicolumn{2}{|c|}{ Venezuela } \\
\hline $\begin{array}{r}\text { Change in } \\
\log \mathrm{PCI}\end{array}$ & $\begin{array}{l}\text { Reported } \\
\text { log income }\end{array}$ & $-0.59 \star$ & $\begin{array}{l}\text { Conditional } \\
\text { convergence }\end{array}$ & $-0.60^{\star}$ & $\begin{array}{l}\text { Conditional } \\
\text { convergence }\end{array}$ \\
\hline Change in $\mathrm{PCI}$ & $\begin{array}{l}\text { Reported } \\
\text { income }\end{array}$ & $-0.10^{\star}$ & $\begin{array}{l}\text { Conditional } \\
\text { convergence }\end{array}$ & $-0.40^{\star}$ & $\begin{array}{l}\text { Conditional } \\
\text { convergence }\end{array}$ \\
\hline $\begin{array}{r}\text { Change in } \\
\log \mathrm{PCI}\end{array}$ & $\begin{array}{l}\text { Predicted } \\
\text { log income }\end{array}$ & 0,09 & None & -0.01 & None \\
\hline Change in $\mathrm{PCI}$ & $\begin{array}{l}\text { Predicted } \\
\text { income }\end{array}$ & 0.00 & None & -0.10 & None \\
\hline
\end{tabular}

*Denotes statistical significance at the $5 \%$ level.

Note: Household characteristics controlled for in the equations include a region dummy, household head's age, gender, schooling level, and initial employment status, changes in household head's gender and employment status, initial family type and its change, and initial number of children and its change.

Source: Author's calculations.

results from the other three countries cannot rule out the null hypothesis of independence. In no case does statistically significant conditional divergence occur: that is, it is never the case that those who start ahead of where they would be expected to be get further ahead.

Overall, the broad prediction of cumulative advantage-that those with higher than predicted initial household income gained more than those households that start below their predicted income--receives no support from these findings.

\section{THE RELATIONSHIP BETWEEN HOUSEHOLD INCOME DYNAMICS AND OTHER HOUSEHOLD CHARACTERISTICS}

The preceding sections showed that average household income changes vary a great deal, depending on households' base-year income. Which other factors are also important in accounting for variation in income change?

To answer this question, we begin with mobility profiles. These are simple relationships between household characteristics and average changes in household income. The mobility profiles are lengthy and are omitted here to conserve space. ${ }^{3}$ Summarizing the results, we find that several variables are státistically significant determinants of household income change. In the case of change in per capita income, the significant variables are change in the number of children and change in family type 
(significant in all four countries); employment status of the head of the household and change in employment status of the head (three); household location, education of the head of the household, number of children, and family type (two); and gender of the head of the household, change in the gender of the head, and age of the household head (one). In the case of change in log PCI, the numbers are only slightly different.

Statistical significance alone indicates nothing about the explanatory importance of these different factors in accounting for income changes. Accordingly, the analysis turned to two other measures.

One indicator of explanatory power is the $\mathrm{R}^{2}$ from a simple regression of income change on each household characteristic, which measures the percentage of variation in income explained by the variation in each household characteristics. These simple $R^{2} s$ are presented in the first column of Tables $2-5 a$ and $2-5 b$ for each country. Far and away the most important variable in explaining the change in $\log \mathrm{PCl}$ is the reported initial income quintile. However, this power is due to an unidentified mix of true initial income and measurement error. Thus, the analysis also takes predicted $\log$ PCI as a proxy for true base-year income. Predicted income quintile remains an important variable in Indonesia and South Africa, but its importance is much diminished as compared with reported base-year income. The next most important variables are changes in employment status and in household composition.

What is remarkable about these results is the unimportance of the head of household's schooling (with one exception) and the head of household's gender (with one exception). Innumerable studies have shown that these variables are enormously important in explaining income levels, so it is somewhat surprising to find that these variables are not only small but in fact statistically insignificant correlates of income changes.

Here is how we interpret these findings. In the profiles and in the regressions without statistical controls, head's education is generally statistically insignificant. However, in multiple regressions used to gauge the ceteris paribus effect of schooling controlling for initial income, the effect of schooling is almost always significantly positive. ${ }^{4}$ Estimates of earnings functions in these and other countries have demonstrated that schooling raises income levels. There are thus two offsetting effects of schooling on income mobility. On the one hand, those with higher base-year income have smaller gains in income, and schooling raises base-year income. On the other hand, once base-year income is controlled for, those with more schooling have more positive gains in income. This may explain why schooling is statistically insignificant without controls but statistically significant (and positive) with controls. The findings for gender may be understood similarly.

The other way in which the study gauges the relative importance of different factors is by using results from a multiple regression to decompose the importance of different household characteristics in explaining variation in the income changes of households. The masses of regression results for different dependent variables, different estimation methods, and different countries would take pages to present; thus, those results are omitted here.

Based on those regressions, the study gauges the importance of one group of variables in the presence of others by using a decomposition of inequality (Fields 2001). 
Table 2-5a Relative Importance of Explanatory Variables on Change in Log Per Capita Income

\begin{tabular}{|c|c|c|c|c|c|c|c|c|c|c|c|c|}
\hline \multirow[b]{2}{*}{ Explanatory variable } & \multicolumn{3}{|c|}{ Indonesia } & \multicolumn{3}{|c|}{ South Africa } & \multicolumn{3}{|c|}{ Spain } & \multicolumn{3}{|c|}{ Venezuela } \\
\hline & $\mathrm{R}^{2}$ & $\mathrm{~S}_{\mathrm{j}}$ & $\mathrm{S}_{\mathrm{j}}$ & $\mathrm{R}^{2}$ & $S_{j}$ & $S_{j}$ & $\mathrm{R}^{2}$ & $\mathrm{~S}_{\mathrm{j}}$ & $\mathrm{S}_{\mathrm{j}}$ & $\mathrm{R}^{2}$ & $\mathrm{~S}_{\mathrm{j}}$ & $\mathrm{S}_{\mathrm{j}}$ \\
\hline Reported initial $\log \mathrm{PCI}$ & $0.286^{\star}$ & $37.7 \%$ & & $0.272^{\star}$ & $36.2 \%$ & & $0.011^{\star}$ & $28.7 \%$ & & $0.072^{\star}$ & $28.1 \%$ & \\
\hline Predicted $\log \mathrm{PCI}$ & $0.026^{\star}$ & & $4.4 \%$ & $0.067^{\star}$ & & $9.1 \%$ & 0.000 & & $0.0 \%$ & 0.000 & & $0.0 \%$ \\
\hline Region & 0.000 & $0.2 \%$ & $0.2 \%$ & $0.014 \star$ & $2.1 \%$ & $1.6 \%$ & 0.002 & $0.0 \%$ & $0.3 \%$ & 0.000 & $0.2 \%$ & $0.0 \%$ \\
\hline Initial number of children & $0.001^{\star}$ & $-0.5 \%$ & $-0.3 \%$ & $0.007^{\star}$ & $-1.9 \%$ & $-1.3 \%$ & 0.002 & $0.6 \%$ & $0.0 \%$ & 0.001 & $0.1 \%$ & $0.0 \%$ \\
\hline Head's gender & $0.003^{\star}$ & $0.0 \%$ & $0.0 \%$ & 0.005 & $-0.4 \%$ & $-0.2 \%$ & $0.046^{\star}$ & $0.4 \%$ & $0.6 \%$ & 0.000 & $0.0 \%$ & $0.0 \%$ \\
\hline Initial family type & 0.000 & $0.0 \%$ & $0.0 \%$ & $0.021^{\star}$ & $-1.4 \%$ & $-0.9 \%$ & 0.000 & $0.1 \%$ & $0.1 \%$ & 0.000 & $0.0 \%$ & $0.0 \%$ \\
\hline Head's age & 0.002 & $0.1 \%$ & $0.0 \%$ & 0.003 & $0.6 \%$ & $0.5 \%$ & 0.007 & $0.5 \%$ & $0.6 \%$ & 0.001 & $0.1 \%$ & $0.0 \%$ \\
\hline Head's schooling & 0.002 & $-0.6 \%$ & $-0.4 \%$ & $0.015^{\star}$ & $0.6 \%$ & $0.8 \%$ & 0.001 & $0.0 \%$ & $0.0 \%$ & 0.001 & $0.1 \%$ & $0.1 \%$ \\
\hline Head's employment status & $0.036^{\star}$ & & & $0.078^{\star}$ & $-2.1 \%$ & $-0.1 \%$ & $0.006^{\star}$ & $-1.1 \%$ & $-0.2 \%$ & $0.005^{\star}$ & $0.1 \%$ & $0.4 \%$ \\
\hline Change in number of children & $0.021 \star$ & $2.2 \%$ & $2.5 \%$ & $0.052^{\star}$ & $6.4 \%$ & $5.8 \%$ & $0.002^{\star}$ & $0.1 \%$ & $0.1 \%$ & 0.000 & $0.0 \%$ & $0.0 \%$ \\
\hline Change in head's gender & $0.008^{\star}$ & $0.3 \%$ & $0.4 \%$ & $0.011^{\star}$ & $0.7 \%$ & $0.6 \%$ & 0.000 & $0.0 \%$ & $0.0 \%$ & $0.007^{\star}$ & $0.0 \%$ & $0.1 \%$ \\
\hline Change in family type & 0.002 & $0.3 \%$ & $0.3 \%$ & $0.048^{\star}$ & $3.9 \%$ & $4.1 \%$ & $0.001^{\star}$ & $0.0 \%$ & $0.0 \%$ & 0.002 & $0.1 \%$ & $0.1 \%$ \\
\hline $\begin{array}{l}\text { Change in head's } \\
\text { employment status }\end{array}$ & $0.062^{\star}$ & $3.0 \%$ & $4.6 \%$ & $0.122^{\star}$ & $8.3 \%$ & $8.6 \%$ & $0.057 \star$ & $6.8 \%$ & $7.6 \%$ & $0.012^{\star}$ & $0.8 \%$ & $1.0 \%$ \\
\hline Total explained & & $42.7 \%$ & $11.7 \%$ & & $52.8 \%$ & $28.8 \%$ & & $36.0 \%$ & $9.0 \%$ & & $29.5 \%$ & $1.7 \%$ \\
\hline Unexplained & & $57.3 \%$ & $88.3 \%$ & & $47.2 \%$ & $71.2 \%$ & & $64.0 \%$ & $91.0 \%$ & & $70.5 \%$ & $98.3 \%$ \\
\hline Total & & $100 \%$ & $100 \%$ & & $100 \%$ & $100 \%$ & & $100 \%$ & $100 \%$ & & $100 \%$ & $100 \%$ \\
\hline
\end{tabular}

¿Denotes statistical significance at the $5 \%$ level.

Note: $\mathrm{R}^{2}$ values correspond to simple OLS regression of change in $\log \mathrm{PCI}$ on corresponding variable. $\mathrm{S}_{\mathrm{j}}$ represents the share of explanatory power of the corresponding variable in a multivariate regression that includes all other variables in the table.

Source: Authors' calculations. 
Table 2-5b Relative Importance of Explanatory Variables on Change in Per Capita Income

\begin{tabular}{|c|c|c|c|c|c|c|c|c|c|c|c|c|}
\hline \multirow[b]{2}{*}{ Explanatory variable } & \multicolumn{3}{|c|}{ Indonesia } & \multicolumn{3}{|c|}{ South Africa } & \multicolumn{3}{|c|}{ Spain } & \multicolumn{3}{|c|}{ Venezuela } \\
\hline & $\mathrm{R}^{2}$ & $\mathrm{~S}_{\mathrm{j}}$ & $S_{j}$ & $\mathrm{R}^{2}$ & $\mathrm{~S}_{\mathrm{j}}$ & $\mathrm{S}_{\mathrm{j}}$ & $\mathrm{R}^{2}$ & $\mathrm{~S}_{\mathrm{j}}$ & $\mathrm{S}_{\mathrm{j}}$ & $\mathrm{R}^{2}$ & $\mathrm{~S}_{\mathrm{j}}$ & $\mathrm{S}_{\mathrm{j}}$ \\
\hline Initial PCI & $0.052^{\star}$ & $9.3 \%$ & & $0.099 *$ & $14.2 \%$ & & $0.025 \star$ & $3.8 \%$ & & $.112^{\star}$ & $18.7 \%$ & \\
\hline Predicted PCI & $0.007^{\star}$ & & $-0.4 \%$ & $0.022^{\star}$ & & $3.5 \%$ & 0.000 & & $0.1 \%$ & 0.001 & & $0.2 \%$ \\
\hline Region & $0.017 \star$ & $1.8 \%$ & $1.3 \%$ & 0.010 & $1.9 \%$ & $1.4 \%$ & 0.000 & $0.0 \%$ & $0.0 \%$ & $0.001^{\star}$ & $0.4 \%$ & $0.2 \%$ \\
\hline Initial number of children & 0.000 & $-0.1 \%$ & $0.0 \%$ & 0.001 & $-0.5 \%$ & $-0.4 \%$ & 0.002 & $0.5 \%$ & $0.1 \%$ & $0.002^{\star}$ & $-0.3 \%$ & $-0.1 \%$ \\
\hline Head's gender & 0.001 & $0.0 \%$ & $0.0 \%$ & 0.004 & $0.1 \%$ & $0.1 \%$ & $0.005^{\star}$ & $0.7 \%$ & $0.7 \%$ & 0.000 & $0.0 \%$ & $0.0 \%$ \\
\hline Initial family type & 0.000 & $0.0 \%$ & $0.0 \%$ & $0.013^{\star}$ & $-2.0 \%$ & $-1.5 \%$ & 0.003 & $0.2 \%$ & $0.4 \%$ & $0.000 \star$ & $0.1 \%$ & $0.1 \%$ \\
\hline Head's age & $0.004^{\star}$ & $0.4 \%$ & $0.4 \%$ & 0.003 & $0.4 \%$ & $0.4 \%$ & 0.011 & $0.7 \%$ & $0.9 \%$ & $0.001 *$ & $0.1 \%$ & $0.1 \%$ \\
\hline Head's schooling & $0.015^{\star}$ & $2.9 \%$ & $1.5 \%$ & 0.006 & $0.2 \%$ & $0.2 \%$ & 0.004 & $0.9 \%$ & $0.4 \%$ & $0.001^{\star}$ & $0.6 \%$ & $0.3 \%$ \\
\hline Head's employment status & $0.020^{\star}$ & & & $0.027^{\star}$ & $-1.5 \%$ & $-0.2 \%$ & 0.004 & $-0.2 \%$ & $0.0 \%$ & $0.007^{\star}$ & $-0.1 \%$ & $0.3 \%$ \\
\hline Change in number of children & $0.023 \star$ & $2.8 \%$ & $2.8 \%$ & $0.050^{\star}$ & $5.0 \%$ & $4.9 \%$ & $0.025^{\star}$ & $2.4 \%$ & $2.4 \%$ & $0.007 \star$ & $0.8 \%$ & $0.7 \%$ \\
\hline Change in head's gender & $0.002^{\star}$ & $0.2 \%$ & $0.2 \%$ & 0.007 & $0.3 \%$ & $0.3 \%$ & 0.001 & $0.0 \%$ & $0.0 \%$ & $0.005^{\star}$ & $0.4 \%$ & $0.5 \%$ \\
\hline Change in family type & 0.000 & $0.0 \%$ & $0.0 \%$ & $0.039 \star$ & $5.0 \%$ & $4.8 \%$ & $0.023 \star$ & $1.8 \%$ & $2.1 \%$ & $0.002 \star$ & $0.1 \%$ & $0.1 \%$ \\
\hline $\begin{array}{l}\text { Change in head's employment } \\
\text { status }\end{array}$ & $0.026^{\star}$ & $1.9 \%$ & $1.9 \%$ & $0.087^{\star}$ & $8.1 \%$ & $7.4 \%$ & $0.033^{\star}$ & $4.3 \%$ & $4.3 \%$ & $0.027^{\star}$ & $2.5 \%$ & $2.5 \%$ \\
\hline Total explained & & $19.2 \%$ & $7.7 \%$ & & $31.0 \%$ & $21.2 \%$ & & $14.9 \%$ & $11.3 \%$ & & $23.3 \%$ & $4.9 \%$ \\
\hline Unexplained & & $80.8 \%$ & $92.3 \%$ & & $69.0 \%$ & $78.8 \%$ & & $85.0 \%$ & $88.7 \%$ & & $76.7 \%$ & $95.1 \%$ \\
\hline Total & & $100 \%$ & $100 \%$ & & $100 \%$ & $100 \%$ & & $100 \%$ & $100 \%$ & & $100 \%$ & $100 \%$ \\
\hline
\end{tabular}

$\star$ Denotes statistical significance at the $5 \%$ level.

Note: $\mathrm{R}^{2}$ values correspond to simple OLS regression of change in $\mathrm{PCI}$ on corresponding variable. $S_{\mathrm{j}}$ represents the share of explanatory power of the corresponding variable in a multivariate regression that includes all other variables in the table.

Source: Authors' calculations. 
The question asked is: how much of the inequality in $\Delta \mathrm{PCI}$ or $\Delta \log \mathrm{PCI}$ among households is attributable to factors such as initial income quintile, education, or age? The shares of different factors in accounting for the observed inequality in mobility experiences appear in the $S_{j}$ columns of Tables $2-5 a$ and $2-5 b$. In the middle column for each country, the decomposition is based on a regression equation using reported income, while the right column reports the factor shares using predicted income instead of reported income.

Looking first at the change in log-currency units, in all four countries, initial income appears as the single most important variable. Two other variables show substantial effects: change in the employment status of the head of household, and change in number of children. The remaining variables account for very little of the inequality in income changes, singly or together. Turning now from change in logs to change in currency units, in Table 2-5b, initial PCI (reported) remains the single most important variable in all countries except Spain, where it is second to the change in head's employment. Change in head's employment is also second in importance in South Africa and Venezuela and third in Indonesia.

Summing up, the multivariate analysis establishes the primary importance of initial economic position and change in household head's employment status in accounting for the observed inequality in income changes. Perhaps surprisingly, human capital characteristics of the household head such as education and age (as a proxy for labor market experience) consistently account for little of the observed inequality in income change. A priority for future research is to better understand the underlying causes of changes in employment status and its potential relation with education.

\section{DECOMPOSING THE SOURCES OF CHANGE IN PER CAPITA INCOME}

We turn now from causes of changing per capita income (or its $\log$ ) to two fundamental decompositions. First, there is a basic accounting question of whether changes in household income or changes in household size drive the changes we observe in their ratio. Change in $\log \mathrm{PCI}$ can be easily decomposed into the portion due to change in the household's log income and the portion due to change in the household's size. We calculate the fraction of households for which the change in log-income accounts for at least half the total change in log PCI.These percentages83 percent in Indonesia, 72 percent in South Africa, 96 percent for Spain, and 88 percent for Venezuela - demonstrate that for the vast majority of households in these countries, it is changes in household income (the numerator) rather than changes in number of household members (the denominator) that account for the bulk of their changes in per capita income.

Next, we seek to find which sources of income drive these income changes. Since our measure of household income in a given year is a sum of various income components, change in household income can be additively decomposed into the change in its component parts. We use two methods for assigning quantitative importance to various income components. One was devised by John Fei, Gustav Ranis, and Shirley Kuo (1978) and Graham Pyatt, Chau-Nan Chen, and John Fei (1980). The other was 
Table 2-6 Factor Inequality Weights for Change in Per Capita Income

\begin{tabular}{llrr}
\hline & & $(1)$ & $(2)$ \\
\hline Indonesia & Labor Earnings & $61.4 \%$ & $71.3 \%$ \\
& Transfer income & $14.6 \%$ & $9.8 \%$ \\
& Remittance income & $23.5 \%$ & $16.2 \%$ \\
& Asset income & $0.5 \%$ & $2.6 \%$ \\
South Africa & Labor earnings & $82.7 \%$ & $88.2 \%$ \\
& Rental & $6.2 \%$ & $4.4 \%$ \\
& Remittance & $3.0 \%$ & $1.6 \%$ \\
& Other non-labor & $8.1 \%$ & $5.8 \%$ \\
Spain & income & & \\
& Labor earnings & $79.5 \%$ & $83.2 \%$ \\
& Capital income & $3.9 \%$ & $3.5 \%$ \\
& Transfer income & $13.9 \%$ & $11.1 \%$ \\
& Other non-labor & $2.7 \%$ & $2.1 \%$ \\
Venezuela & income & & \\
& Labor earnings & $89.8 \%$ & $88.9 \%$ \\
& Private transfers & $3.1 \%$ & $3.0 \%$ \\
& Social Security & $3.2 \%$ & $4.2 \%$ \\
& Other non-labor & $3.9 \%$ & $3.9 \%$ \\
& income & & \\
\hline
\end{tabular}

(1) Fei, Ranis, and Kuo (1978); Pyatt, Chen, and Fei (1980) and (2) Shorrocks (1982). Note: All income sources are in per capita terms.

Source: Authors' calculations, based on methods devised by Fei, Ranis, Kuo (1978);

Pyatt, Chen, and Fei (1980); and Shorrocks (1982).

developed by Anthony Shorrocks (1982). The results of these decompositions appear as the factor inequality weights displayed in Table 2-6. The share of inequality in per capita income changes accounted for by labor earnings ranges from approximately two-thirds for Indonesia to nearly 90 percent in Venezuela. For these four countries the message is strikingly clear: change in labor income is the most important source of change in total income.

In sum, this section has reached two main conclusions. First, for the great majority of households, change in household income is more important than change in family size in accounting for change in $\log$ PCI. Second, change in household income is attributable more to change in labor earnings than to change in non-labor income. These results do not imply that changes in household composition have a small total effect on household income, since the entrance and exits of household members often have a direct effect on households' labor income. These conclusions, however, along with the employment dynamics results in the previous section, point to the need for further research on the changes in households' labor market earnings as a vital component in understanding changes in economic well-being.

\section{ESCAPES FROM POVERTY}

Up to this point, we have looked at the determinants of income changes in all parts of the income distribution. We now turn to analyzing the dynamics of poverty in the four countries, using country-specific poverty lines. Throughout this analysis, the term 
Table 2-7 Percentage of Households by Poverty Experience

\begin{tabular}{lllllr}
\hline Country & $\begin{array}{l}\text { Total } \\
\text { number of } \\
\text { households }\end{array}$ & $\begin{array}{l}\text { Percent } \\
\text { non-poor } \\
\text { both periods }\end{array}$ & $\begin{array}{l}\text { Percent } \\
\text { poor both } \\
\text { periods }\end{array}$ & $\begin{array}{l}\text { Percent } \\
\text { exiting } \\
\text { poverty }\end{array}$ & $\begin{array}{r}\text { Percent } \\
\text { entering } \\
\text { poverty }\end{array}$ \\
\hline Indonesia & 5,370 & $76.0 \%$ & $3.9 \%$ & $14.0 \%$ & $6.0 \%$ \\
South Africa & 820 & $33.5 \%$ & $34.2 \%$ & $18.5 \%$ & $13.8 \%$ \\
Spain & 1,245 & $79.5 \%$ & $10.9 \%$ & $6.2 \%$ & $3.1 \%$ \\
Venezuela & 7,516 & $35.5 \%$ & $35.9 \%$ & $15.7 \%$ & $12.9 \%$ \\
\hline
\end{tabular}

Source: Authors' calculations.

"exiting poverty" implies being poor in period one and rising out of poverty in period two. The analysis of escaping poverty will be conducted on the subsample of households poor in the initial period. Likewise, the analysis of "entering poverty". will be conducted on households that were not poor in the initial period.

Table 2-7 provides the weighted percentages of households in our samples that were not poor in either period, that were poor in both periods, that escaped poverty, and that entered poverty. In each of the four countries poverty rates declined, since more households exited poverty than entered poverty. Indonesia is notable for its extremely low percentage of persistent poverty (poor in both periods) compared to transient poverty (leaving or entering poverty). This finding is consistent with findings on poverty dynamics in Indonesia after that country's financial crisis in 1998. In contrast to Indonesia, where fewer than 30 percent of households that were poor initially remained poor, income poverty was more permanent in the other countries: 71 percent of poor households in Venezuela, 65 percent of poor households in South Africa, and 64 percent of poor households in Spain remained poor.

Other things equal, which household characteristics are correlated with escaping poverty and which with entering poverty? To answer these questions, we estimated the probability of escaping and entering poverty using a number of logit models. Three variables were found to be consistently and significantly associated with poverty exits in the four countries: a change in employment by the head of household, the region of residence, and the number of children in the household. Changes in employment status of the head are significant in explaining transitions out of poverty for all countries. In all countries except Venezuela, these job changes were not only statistically significant, but also had the largest effect on the probability of escaping poverty among statistically significant variables. In Indonesia, Spain and South Africa, the probability of escaping poverty varies by over 20 percentage points, depending on the employment transitions of the head.

While employment changes are significant determinants of poverty escapes in each country, as expected, some other relationships between employment changes and escape rates were unexpected. In Indonesia, if the household head started in the formal sector, escape rates were similar whether the head worked in the final period or not. In South Africa, if the household head in a poor family left the formal private sector, the household was much more likely to escape poverty than if the head remained in the formal private sector. Additionally, South African households where the head 
entered the informal sector were less likely to have exited poverty than households where the head entered the inactive status.

Finally, we probed further the relationship between poverty transitions and the head's job category in the base and final year (where data are available). The main finding is that households where the head was involved with the public sector escaped poverty and avoided falling into poverty at above-average rates. However, public sector employment is a small fraction of total employment in the three countries for which data are available and therefore few of the households that escaped poverty had the head working in the public sector.

Table 2-8 shows the distribution of transitions out of poverty by head's employment category. ${ }^{5}$ For countries where the data are available, these figures show that the private sector accounts for a much larger proportion of poverty escapes than does the public sector.

The analysis of poverty transitions yields the following conclusions. First, changes in the head of household's employment, region of residence, and number of children in the household are important correlates of entering and escaping poverty. Second, households with heads working in the public sector have a higher probability of escaping poverty

Table 2-8 Distribution of Poverty Escapes by Houschold Head's Base-year and Final-year Job Category

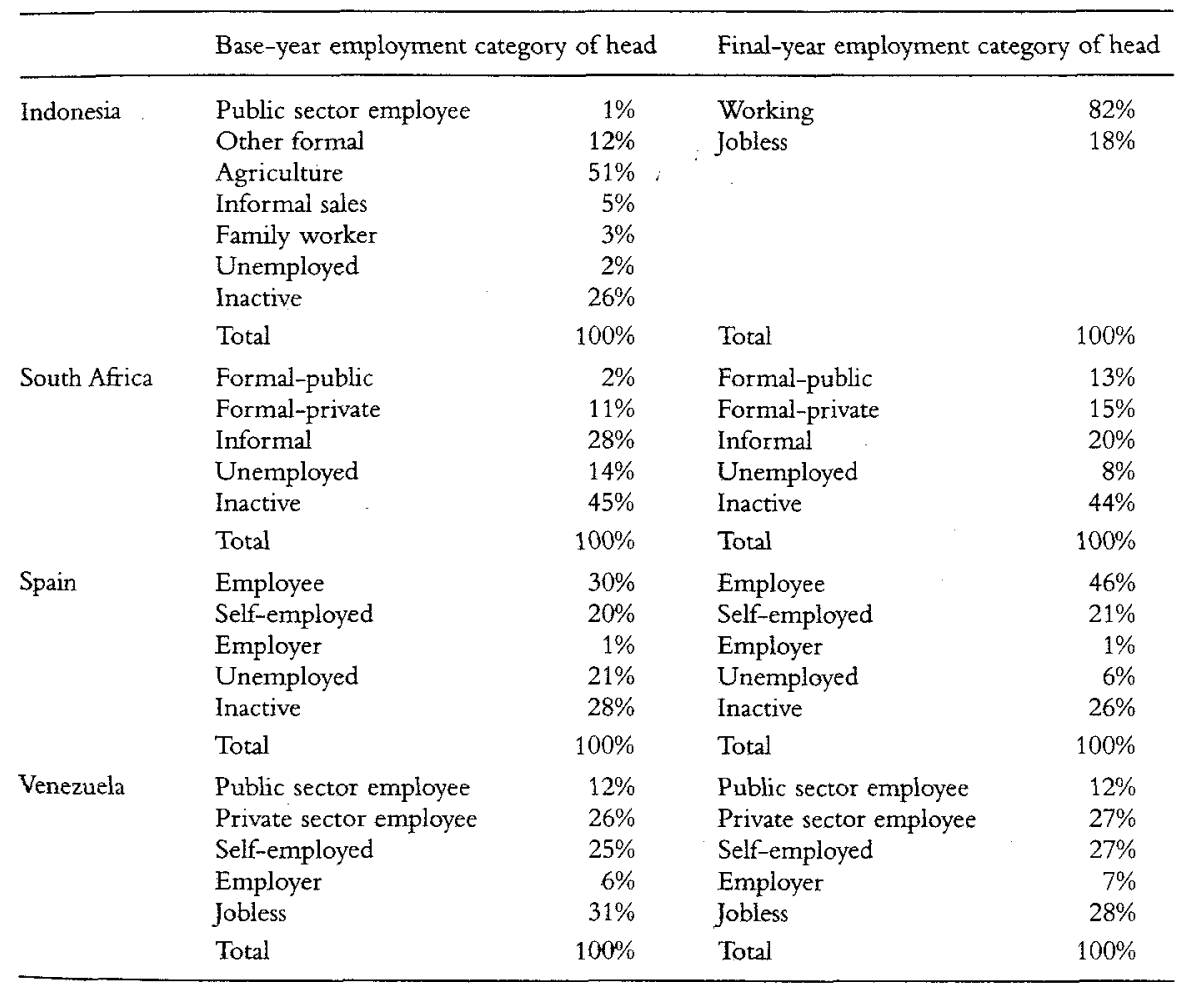


than households with heads working in the private sector. Third, of the households that escaped poverty, many more of the heads worked in the private sector than in the public sector. Thus, the private sector is the main engine to help families escape poverty.

\section{CONCLUSIONS}

This study has examined change in per capita household income, in both logarithmic and monetary terms, in four very diverse economies-Indonesia, South Africa, Spain, and Venezuela-in the 1990s. Despite differences in types of data, years of observation, macroeconomic conditions, and income levels, major patterns-some expected and some unexpected-emerged.

The first question was which households gained the most in terms of per capita income over the period: those that were advantaged, initially, or those that-were disadvantaged, initially. In all four countries, the households that reported lower initial incomes experienced more favorable income changes than those that reported higher initial incomes. That is, those households that reported low base-year income experienced the highest or most positive average income gains. Those with high base-year income experienced the lowest or most negative average changes.

Because measurement error in initial income could lead reported incomes to overstate convergence, the study also approximated longer-term base-year income by predicted income. Using this measure yielded a similar result in log terms. The households that were predicted to be poor, initially, experienced the highest log-income gains in all four countries. However, in currency unit terms, the results were mixed. When predicted incomes were used, South Africa andVenezuela continued to exhibit convergent patterns, Indonesia exhibits a divergent pattern, and Spain may have had a divergent pattern.

Overall, our work gives very little support to those who argue that the poor are being left out or are being made poorer, at least in these four countries. Rather, in all four countries, initially poor households experienced more favorable income changes than their richer counterparts, when changes are measured in percentage terms. And when changes are measured in currency units, we find that in South Africa and Venezuela, initially poor households experienced greater absolute income gains than did initially rich households.

The second question was whether income changes move households closer to the incomes that would be predicted on the basis of their observed characteristics, or further away. Using reported initial income, the evidence in all four countries overwhelmingly supports convergence to the household's conditional expected incomewhich is consistent with models in which the effect of income shocks decays over time. Results are mixed when using predicted initial income. However, nowhere does the evidence support statistically significant conditional divergence, whereby the rich get relatively richer (that is, positive shocks produce upward spirals) and the poor get relatively poorer (negative shocks produce downward ones).

Third, of the variety of factors besides initial income that are possible determinants of per capita income changes, changes in the employment sector of the household 
head appeared as a quantitatively important variable in all four countries. This is not surprising. What is surprising, at least to us, is that in three of four countries, no important role emerged either for the education of the head of household or for the head's gender in accounting for changes in per capita income.

Fourth, for over 70 percent of households in each country, the change in per capita income was primarily accounted for by their change in income and not by the change in their number of household members. In addition, in each country, changes in labor earnings are more important causes of change in household income than are changes in all other income sources combined.

Finally, transitions out of or into poverty are most strongly influenced by transitions of the head of household's employment. Public sector employment of the household head substantially increases the likelihood of escaping from poverty, but accounts for relatively few such escapes. Most households that escaped poverty were headed by private sector workers rather than public sector workers.

Returning to the larger issue with which this analysis began, overall we have found that even in today's highly globalized world, in these four countries, poor households have participated at least proportionately in the economic growth that has taken place. In at least two of the four countries, they have gained more in currency units, as well. These results emphasize the important role policies that spur economic growth and promote a favorable investment climate play in bringing tangible economic benefits to the world's poor.

Lastly, from the point of view of further research, the findings about the labor market are of particular interest. The study found that initial income and job changes of the head of household are consistently the most important variables in explaining change in per capita income. Changes in income are more important than changes in household size, and changes in labor earnings are more important than changes in all other sources of household income combined. These findings emphasize the importance of studies and policies that promote labor market growth in the pursuit of a world free from poverty.

\section{REFERENCES}

Fei, John C. H., Gustav Ranis, and Shirley W.Y. Kuo. 1978. "Growth and the Family Distribution of Income by Factor Components." Quarterly Journal of Economics 92 (1): 17-51.

Fields, Gary S. 2001. "Accounting for Income Inequality and Its Change: A New Method, with Application to the Distribution of Earnings in the United States." Cornell University. Processed.

Fields, Gary S., Paul L. Cichello, Samuel Freje, Marta Menéndez, and David Newhouse. 2001. "Household Income Dynamics: A Four Country Story." Final Report to the International Finance Corporation (June).

. 2002. "For Richer or For Poorer? Evidence from Indonesia, South Africa, Spain and Venezuela." Cornell Universiry. Processed.

Friedman, Milton, and Simon Kuznets. 1945. Income from Independent Professional Practice. New York: National Bureau of Economic Research.

Merton, Robert K. 1968. "The Matthew Effect in Science." Science 159 (3810): 56-63.

Pyatt, Graham, Chau-Nan Chen, and John Fei. 1980. "The Distribution of Income by Factor Components." Quarterly Journal of Economics 95 (3): 451-73.

Shorrocks, Anthony F. 1982. "Inequality Decomposition by Factor Components." Econometrica 50 (1): 193-211. 


\section{NOTES}

$\star$ The authors would like to thank the International Finance Corporation for financial support.

${ }^{1}$ The data sources and years of coverage for each country are as follows: (Indonesia) the Indonesian Family Life Survey for 1993 and 1997; (South Africa) KwaZulv-Natal Income Dynamics Study for 1993 and 1998; (Spain) the Spanish Household Panel Survey (Encuesta Contínua de Presupuestos Familiares) from 1995 and 1996; (Venezuela) the Venezuelan Sample Household Survey (Encuesta de Hogares por Muestreo) from 1997 and 1998.

${ }^{2}$ The latter two items were used in Indonesia and South Africa, only.

${ }^{3}$ The profiles appear in detail in the full study (Fields and others 2001).

${ }^{4}$ The regressions are omitted here for space reasons but are available upon request.

${ }^{5} \mathrm{~A}$ similar table for transitions into poverty is omitted for space reasons. 